\title{
21. PETROLEUM-GENERATING POTENTIAL AND THERMAL HISTORY OF DSDP LEG 38 SEDIMENTS ${ }^{1}$
}

\author{
A. Hood, J.R. Castaño, and J.W. Kendrick, Shell Development Company, \\ Bellaire Research Center, P.O. Box 481, Houston, Texas
}

\section{INTRODUCTION AND SUMMARY}

Seven frozen core samples from DSDP Leg 38 have been analyzed in terms of their petroleum source-rock characteristics-principally richness and thermal history. In addition, 32 samples were used for comparison of two organic-richness parameters: organic carbon content and pyrolysis-fluorescence (PF).

From the study it is concluded that (1) it is doubtful that any of the analyzed sediments contains enough hydrocarbon-generating (effective) organic matter to be considered a potential source rock for significant oil accumulations, and (2) none has had a sufficient temperature history to reach the main catagenetic stage of oil generation. The effective carbon contents $\left(\mathrm{C}_{\mathrm{eff}}\right)$ do not exceed $0.22 \%$, and the highest level of organic metamorphism (LOM) observed is about 7. This is equivalent to the boundary between subbituminous B and high-volatile $\mathrm{C}$ bituminous coal rank.

\section{ANALYTICAL METHODS}

Temperature history has been determined by measurement of the reflectance of vitrinite, a coal maceral which is disseminated in many sediments. Vitrinite reflectance provides a measure of organic metamorphism which is applicable over a wide range of coal rank, stage of catagenesis (Vassoyevich et al., 1970), or level of organic metamorphism (LOM; Hood and Castaño, 1974; Hood et al., 1975).

Organic richness is often based on determinations of total organic carbon contents of sediments. It is important, though, particularly for sediments with little burial, to have a measure of the effective organic carbon content, i.e., the portion of the total organic carbon which is converted to petroleum during burial to great depths and temperatures. As measures of effective organic carbon we have used laboratory pyrolysis methods. One method-pyrolysis-FID (P-FID) - determines the percentage of hydrocarbons generated in the laboratory temperature range of $300^{\circ}$ to $650^{\circ} \mathrm{C}$. It approximates the percentage of hydrocarbons generated at lower temperatures in the subsurface. The second pyrolysis method-pyrolysis fluorescence (PF) -is used mainly as a rapid screening tool and measures the amount of fluorescing organic matter formed by pyrolysis (in arbitrary PF units). These analytical methods are described below.

'BRC-EP Publication No. 685, Shell Development Company (a Division of Shell Oil Company).

\section{Vitrinite Reflectance}

American Society for Testing Materials procedures are employed for preparation and examination of polished specimens (ASTM D 2797; ASTM, 1970). Where coal macerals are accessory constituents, it is necessary to concentrate the organic matter. This is a two-step treatment with hydrochloric and hydrofluoric acid which provides an organic-rich separate. Reflectance determinations are made with a reflecting microscope equipped with a stabilized D.C. power supply and a photomultiplier. Typical working magnification is 630 $X$; the measuring aperture at this magnification is about $3 \mu \mathrm{m}$. For the interpretation of vitrinite reflectance data in noncoal-bearing rocks, see Castaño and Sparks (1974) and Hood and Castaño (1974). During the measurement of reflectance of vitrinite particles, a qualitative visual estimate of organic types is made.

\section{Total Organic Carbon Content}

The carbonates (and other acid-soluble portions) of the sample are removed by treatment with $6 N \mathrm{HCL}$. The leached residue is then combusted under a stream of oxygen in a LECO induction furnace and the produced $\mathrm{CO}_{2}$ is measured gasometrically. The volume of $\mathrm{CO}_{2}$, the leaching factor, and the sample weight are used to calculate the concentration of noncarbonate carbon in the original sample.

\section{Pyrolysis-FID (P-FID)}

A small sample of rock (usually less than $200 \mathrm{mg}$ ) is heated in a flowing stream of pure nitrogen at temperatures increasing from room temperature to $650^{\circ} \mathrm{C}$ at a rate of $25^{\circ} \mathrm{C}$ per minute. The volatile organic compounds are distilled off at temperatures less than about $300^{\circ} \mathrm{C}$. At higher temperatures nonvolatile organic matter is pyrolyzed to form a carbon-rich gas. The distillation and pyrolysis products are carried by nitrogen to a hydrogen flame ionization detector (FID). The FID signal can be converted to \% carbon or \% hydrocarbons (volatile and/or pyrolysis) by calibration with a petroleum wax. For further information on the method and instrumentation, see Eggertsen and Stross (1972).

\section{Pyrolysis-Fluorescence (PF)}

Pyrolysis-fluorescence involves a test-tube pyrolysis of a fine-grained sediment followed by measurement of fluorescence of the organic-soluble products (Heacock and Hood, 1970). A 0.1-g sample is weighed into a $10 \times$ $75 \mathrm{ml}$ culture tube, heated over a Bunsen burner until the tube and sample become red, and then allowed to cool. Three $\mathrm{ml}$ of chlorothene (1,1,1-trichloroethane) are added, and the contents are poured into a clean tube, 
which is then transferred to a fluorometer for measurement of the amount of soluble fluorescing products. We use a Turner Model 110 fluorometer, modified by the addition of a $99 \%$ opaque neutral density filter to bring the sensitivity within the desired range. Samples with fluorometer scale readings greater than 20 are diluted with equal or known greater volumes of chlorothene until the reading is less than 20 to avoid self-absorption effects. Using the appropriate dilution factor, PF units are calculated as scale readings per $0.1 \mathrm{~g}$ of sample in 3 $\mathrm{ml}$ of solvent.

\section{RESULTS AND DISCUSSION}

Sample identifications and analytical results are shown in Tables 1 and 2. All of the samples are from 20$\mathrm{cm}$ geochemical cores from DSDP Leg 38, and they represent most of the analyzed geochemical cores from that leg containing greater than $1 \% \mathrm{C}_{\text {org }}$. Seven samples were received as frozen cores (Table 1). Thirty-two additional samples (Table 2) are homogenized samples which had been analyzed for organic carbon by Dr. J.G. Erdman of Phillips Petroleum Company. The 32 samples were used to compare PF with organic carbon contents.

\section{Temperature History}

The observed values of vitrinite reflectance (Table 1: $\mathrm{R}_{\mathrm{o}}=0.28 \%-0.46 \%$ ) are equivalent to LOM values $\leq 7$ and to coal ranks varying from lignite to the boundary between subbituminous B and high-volatile C bituminous coal. This indicates that these sediments have not reached the principal zone of oil generation (LOM 7.8-11.6).

\section{Organic Richness}

Numerous values of organic carbon content have been suggested as minimum requirements for petroleum source rocks. Ronov (1958) concluded that the critical $\mathrm{C}_{\text {org }}$ value for source rocks of economic petroleum accumulations lies somewhere between the average values for clays of petroliferous (1.4\%) and nonpetroliferous $(0.4 \%)$ areas of the Russian Platform-and probably closer to the former. This suggests a minimum value of about $1.0 \% \mathrm{C}_{\text {org }}$ Schrayer and Zarella (1963) reported a value of about $1.5 \% \mathrm{C}_{\text {org }}$ as a minimum requirement for oil source rocks based on studies of the Mowry Shales of Wyoming. The organic carbon contents reported in Table 1 for seven Leg 38 cores range from $0.62 \%$ to $1.66 \%$. The above criteria would indicate that these samples are borderline oil source rocks.

The values determined for \% hydrocarbons generated during laboratory pyrolysis of those samples are all $0.26 \%$ or less (Table 1). Effective carbon contents (calculated as $85 \%$ of the pyrolysis hydrocarbon content) are $0.22 \%$ or less. In view of the low values of pyrolysis hydrocarbons and effective carbon, it seems doubtful that any of these samples should be considered as potential (future) oil source rocks. This conclusion is supported by the low PF values ( $<10$ PF units) for all of the cores in Tables 1 and 2. As a rule of thumb, we eliminate sediments with $\mathrm{PF}<30$ from consideration as potential source rocks for economic oil accumulations.

During the microscopic measurement of reflectance of vitrinite particles, we made visual estimates of the types of organic material in the sediments, i.e., amorphous, exinitic, and humic (Table 1). Although the

TABLE 1

Analytical Results for Frozen Geochemical Cores

\begin{tabular}{|c|c|c|c|c|c|c|c|c|c|}
\hline $\begin{array}{c}\text { Sample } \\
\text { (Interval in cm) }\end{array}$ & Age & $\begin{array}{l}\text { Vitrinite } \\
\text { Reflectance } \\
\text { in Oil } \\
\left(\% \mathrm{R}_{\mathrm{o}}\right)\end{array}$ & $\mathrm{LOM}^{\mathrm{a}}$ & $\begin{array}{l}\text { Equiv. } \\
\text { Coal } \\
\text { Rank }\end{array}$ & $\begin{array}{l}\text { Total } \\
\% \mathrm{C}_{\text {org }}\end{array}$ & $\begin{array}{l}\text { \% HC from } \\
\text { P-FID } \\
\left(300^{\circ}-650^{\circ} \mathrm{C}\right)\end{array}$ & $\begin{array}{l}\text { Effective } \\
\% \mathrm{C}_{\text {org }} \\
(\% \mathrm{HC} \\
\times 0.85) \\
\end{array}$ & $\begin{array}{c}\text { PF } \\
\text { (Arbitrary } \\
\text { Units) }\end{array}$ & $\begin{array}{l}\text { Visual Kerogen } \\
\text { Analy sis }^{\mathrm{b}}\end{array}$ \\
\hline $338-8-2,130-150$ & M. Miocene & 0.46 & 7 & $\begin{array}{l}\text { Subbit B- } \\
\text { Hi Vol C Bit }\end{array}$ & 1.48 & 0.18 & 0.15 & 3 & $\begin{array}{l}\text { Humic (A), } \\
\text { Exinitic (VC), } \\
\text { Reworked humic (A) }\end{array}$ \\
\hline $341-30-5,130-150$ & M. Miocene & 0.42 & 7 & Subbit B & 1.11 & 0.17 & 0.15 & 1 & $\begin{array}{l}\text { Humic (A), } \\
\text { Amorphous (C), } \\
\text { Exinitic (R), } \\
\text { Reworked humic (C) }\end{array}$ \\
\hline $341-32-5,130-150$ & M. Miocene & 0.42 & 7 & Subbit B & 1.66 & 0.23 & 0.20 & 3 & $\begin{array}{l}\text { Amorphous (VC), } \\
\text { Humic (C), } \\
\text { Reworked humic (C) }\end{array}$ \\
\hline $341-34-5,130-150$ & M. Miocene & 0.36 & $<7$ & Lignite & 1.64 & 0.26 & 0.22 & 3 & $\begin{array}{l}\text { Amorphous (VC), } \\
\text { Humic (C), } \\
\text { Reworked humic (C) }\end{array}$ \\
\hline $344-5-5,130-150$ & $\begin{array}{l}\text { Pliocene- } \\
\text { Pleistocene }\end{array}$ & 0.32 & $<7$ & Lignite & 0.62 & 0.02 & 0.02 & 0 & $\begin{array}{l}\text { Humic (A), } \\
\text { Exinitic (R), } \\
\text { Reworked humic (R) }\end{array}$ \\
\hline $344-27-3,130-150$ & Pliocene & 0.34 & $<7$ & Lignite & 0.62 & 0.07 & 0.06 & 1 & $\begin{array}{l}\text { Humic (A), } \\
\text { Reworked humic (R), } \\
\text { Exinitic (VR) }\end{array}$ \\
\hline $346-10-4,130-150$ & M. Miocene & 0.28 & $<7$ & Lignite & 1.10 & 0.08 & 0.07 & 7 & $\begin{array}{l}\text { Humic (A), } \\
\text { Reworked humic (R), } \\
\text { Exinitic (R), } \\
\text { Amorphous (R) }\end{array}$ \\
\hline
\end{tabular}

\footnotetext{
${ }^{a}$ All $R_{0}$ values less than $0.4 \%$ are assigned the LOM value $<7$ because of the difficulty of resolving the LOM $0-7$ range by means of vitrinite reflectance. $R_{\mathrm{O}}$ values $\geqslant 0.4 \%$ are converted to LOM on the basis of Castano's $R_{\mathrm{O}}-\mathrm{LOM}$ relationship (Hood and Castano, 1974).

${ }^{\mathrm{b}}$ Abbreviations: A, abundant; C, common; $\mathrm{R}$, rare; $\mathrm{V}$, very.
} 
TABLE 2

Analy tical Results from Geochemical Cores

\begin{tabular}{|c|c|c|c|}
\hline $\begin{array}{c}\text { Sample } \\
\text { (Interval } \\
\text { in } \mathrm{cm} \text { ) }\end{array}$ & Age & $\begin{array}{c}\text { \% Organic } \\
\text { Carbona } \\
\left(\mathrm{C}_{\text {org }}\right)\end{array}$ & $\begin{array}{l}\text { Py roly sis-Fluorescence } \\
\text { (PF, Arbitrary Units) }\end{array}$ \\
\hline $338-8-3,130$ & M. Miocene & 1.36 & 5 \\
\hline $338-8-3,150$ & & 2.11 & 3 \\
\hline $338-11-2,130$ & M. Miocene & 0.90 & 5 \\
\hline $338-11-2,150$ & & 0.80 & 3 \\
\hline $338-13-5,130$ & E. Miocene & 1.37 & 1 \\
\hline $338-13-5,150$ & & 1.07 & 3 \\
\hline $338-17-5,130$ & E. Miocene & 1.50 & 4 \\
\hline $338-17-5,150$ & & 1.51 & 8 \\
\hline $341-2-1,150$ & Pleistocene & 0.91 & 0 \\
\hline $341-4-1,130$ & $\begin{array}{l}\text { Pleistocene (mixed with } \\
\text { Olig., Mio., and Pliocene) }\end{array}$ & 0.91 & 1 \\
\hline $341-6-2,130$ & Pleistocene (mixed) & 0.92 & 1 \\
\hline $341-30-5,130$ & M. Miocene & 1.77 & 2 \\
\hline $341-30-5,150$ & & 1.27 & 2 \\
\hline $341-32-5,130$ & M. Miocene & 2.41 & 0 \\
\hline $341-32-5,150$ & & 1.69 & 5 \\
\hline $341-34-5,130$ & M. Miocene & 1.74 & 7 \\
\hline $342-6-1,130$ & E. Miocene & 1.14 & 7 \\
\hline $342-6-1,150$ & & 1.08 & 3 \\
\hline $343-7-3,130$ & E. Eocene & 0.97 & 0 \\
\hline $343-7-3,150$ & & 1.32 & 0 \\
\hline $343-9-1,150$ & E. Eocene & 1.34 & 4 \\
\hline $344-5-5,130$ & Plio.-Pleistocene & 1.72 & 0 \\
\hline $344-11-1,130$ & Undated & 1.61 & 3 \\
\hline $344-15-4,130$ & Pliocene & 0.95 & 0 \\
\hline $344-15-4,150$ & & 1.05 & 0 \\
\hline $344-27-3,130$ & Pliocene & 1.14 & 1 \\
\hline $344-27-3,150$ & & 1.28 & 1 \\
\hline $346-10-4,130$ & M. Miocene & 1.35 & 1 \\
\hline $346-10-4,150$ & & 1.32 & 0 \\
\hline $346-12-4,130$ & Undated & 0.92 & 4 \\
\hline $348-3-5,130$ & Pleistocene & 1.43 & 0 \\
\hline $350-10-3,130$ & Oligocene & 0.96 & 2 \\
\hline
\end{tabular}

${ }^{a}$ Analyses courtesy of J. G. Erdman.

estimates were qualitative, it appears that all of the seven samples contain significant proportions of allochthonous organic material which is thermally inert and/or highly oxygenated. This may explain in part the low petroleum potential in these samples.

\section{REFERENCES}

American Society for Testing Materials, 1970. 1970 Book of ASTM Standards: Gaseous fuels, coal, and coke, pt. 19, Philadelphia.

Castano, J.R. and Sparks, D.M., 1974. Interpretation of vitrinite reflectance measurements in sedimentary rocks, and determination of burial history using vitrinite reflectance and authigenic minerals. In Dutcher, R.R., et al., $\mathrm{C}$,arbonaceous materials as indicators of metamorphism: Geol. Soc. Am. Spec. Paper 153, p. 31-52.

Eggertsen, F.T. and Stross, F.H., 1972. Flame detection method for determining organic carbon in water: Anal. Chem., v. 44 , p. $709-714$.
Heacock, R.L. and Hood, A., 1970. Process for measuring the live carbon content of organic samples: U.S. Patent 3,508,877, April 28, 1970.

Hood, A. and Castano, J.R., 1974. Organic metamorphism: Its relationship to petroleum generation and application to studies of authigenic minerals: CCOP Tech. Bull., v. 8, p. 85-118.

Hood, A., Gutjahr, C.C.M., and Heacock, R.L., 1975. Organic metamorphism and the generation of petroleum: Am. Assoc. Petrol. Geol. Bull., v. 59, p. 986-996.

Ronov, A.B., 1958. Organic carbon in sedimentary rocks (in relation to the presence of petroleum): Geochemistry (a translation of Geokhimiya), no. 5, p. 510-536.

Schrayer, G.J. and Zarella, W.M., 1963. Organic geochemistry of shales - I. Distribution of organic matter in the siliceous Mowry Shale of Wyoming: Geochim. Cosmochim. Acta, v. 27, p. 1033-1046.

Vassoyevich, N.B., Korchagina, Yu. I., Lopatin, N.V., and Chernyshev, V.V., 1970. Principal phase of oil formation: Internatl. Geol. Rev., v. 12, p. 1276-1296. 